DOI: $10.33184 / Y V D K-2021-04-30.3$

Э.В. Исхакова (асn. БашГУ, г. Уфа)

\title{
ПЕРЕВОД АНТРОПОЦЕНТРИЧЕСКИХ АНОМАЛЬНЫХ ФРАГМЕНТОВ В ХУДОЖЕСТВЕННЫХ ТЕКСТАХ ДЖ. БАРНСА
}

B статье исследуется понятие антропочентризма в постмодернистских текстах, в частности, на примере романа Дж. Барнса «Артур и Джордж» (2005). Исследовань антропоцентрические аномальные фрагменты текста 6 оригинале и его переводе, осуществленном Е. Петровой в 2019 году. Предпринимается попытка доказать необходимость вылеления аномальных фрагментов $u$ обращения $\kappa$ интертекстуальным источникам.

Ключевые слова: художественный текст, антропоцентризм, перевод

The author of the article studies the concept of anthropocentrism in the postmodern text "Arthur and George" (2005) written by J. Barnes. The anthropocentric anomalous fragments of the original text and its translation made by E. Petrova in 2019 are analyzed. An attempt to prove the necessity of identification of anomalous fragments with intertextual sources is made.

Key Words: literary text, anthropocentrism, translation

\begin{abstract}
Внимание исследователей привлекают различные направления изучения текста, среди которых одним из приоритетных является исследование явления антропоцентризма в рамках художественного текста. Актуальность темы исследования обусловлена малоизученностью вопроса перевода антропоцентрических фрагментов в художественных текстах.

Цель исследования связана с изучением способов перевода антроцентрических аномальных фрагментах на примере постмодернистских текстов Дж. Барнса. Задачи статьи включают рассмотрение понятия антропоцентризма; выявление в
\end{abstract}


художественных текстах английского писателя Дж. Барнса антропоцентрических элементов и их анализ в аспекте перевода.

В лингвистических работах понятие антропоцентризма рассматривается в различных аспектах, а именно, как свойство языка, его структуры и содержания, а также как «способ описания и моделирования» [Мандрикова 2011: 10] языка.

Понятие антропоцентризма берет свое начало из антропоцентрического подхода в лингвистике, которая имеет давнюю историю. Немецкий ученый В. фон Гумбольдт высказал идею о языке как науке на антропоцентрических началах. По его мнению, «изучение языка служит цели познания человеческого духа самого себя» [Ворожбитова 2005: 234]. Идеи, выдвинутые В. фон Гумболдтом, нашли отражение в работах А.А. Потебни. Он размышлял об антропоцентричном развитии языка, утверждал, что «... язык развивается только в обществе» [Кубрякова 1991: 87].

При антропоцентрическом подходе центральное место занимает человек, а язык выступает важнейшим свойством личности. Отмечается, что тексты, созданные человеком, отображают динамику мысли, а мысли передаются с помощью языковых средств. Антропоцентризм художественного текста выражается в том, что любой текст связан с человеком и является фактором культуры. М.М. Бахтин отмечает, что «человек ...выражает себя, создает текст» [Бахтин 1986].

Принцип антропоцентризма в художественных текстах проявляется при обращении к образам автора, читателя и персонажа в их разных ролях. Автор выступает адресантом информации и главным создателем художественного текста, читатель выступает адресатом созданного текста, а персонаж посредник между автором и читателем, посредством которого автор выражает мысли и общается с читателем. Антропоцентричность художественного текста, по мнению Кахаренко В.А., выражается не только в обращении к образам автора и читателя, но и в том, что человек в тексте выступает текстовым «персонажем» [Кухаренко 1991: 37].

В художественных текстах антропоцентризм может проявляться по-разному: при описании жизни людей, их отношений и чувств, а также когда представители животного мира говорят и действуют как люди, олицетворяя их роли и черты 
характера. Эти признаки наблюдаются при анализе художественных текстов английского постмодерниста Джулиана Барнса.

В художественном тексте «Артур и Джордж» (2005) появляются антропологические аномальные фрагменты, которые связаны с особенностями характера персонажей, их имен, мотивов с ними связанных. Сюжет художественного текста повествует о жизни двух главных героев Артура и Джорджа. Обращение к явлению интертекстуальности позволяет более точно передать «смысловое наполнение» [Морозкина, Терентьев 2020: 927] текста при переводе.

Приведем анализ некоторых антропоцентрических аномальных фрагментов, выделенных из текста Дж. Барнса «Артур и Джордж». Антропологические аномальные фрагменты, прежде всего, связаны с героем Артуром и передают особенности атрибутов одежды персонажа:

\begin{tabular}{|c|c|}
\hline $\begin{array}{c}\text { Оригинал } \\
\text { «Артур и Джордж» }\end{array}$ & Перевод Е. Петровой \\
\hline $\begin{array}{l}\text { "Then he gets to his feet, } \\
\text { collects his hat and coat, and } \\
\text { departs" [Barnes 2005: 286] }\end{array}$ & $\begin{array}{l}\text { «Потом он встает и, } \\
\text { взяв шляпу и пальто, уходит» } \\
{[\text { Барнс 2019: 336] }}\end{array}$ \\
\hline $\begin{array}{l}\text { "A turned-up collar and a } \\
\text { muffler, together with a raised } \\
\text { newspaper in the train ..." } \\
\text { [Barnes 2005: 288] }\end{array}$ & \begin{tabular}{l}
\multicolumn{4}{c}{ «однятый воротник и } \\
шарф, а в поезде еще и \\
развернутая газета...» [Барнс \\
2019: 339]
\end{tabular} \\
\hline
\end{tabular}

Чтобы понять смыслы данных антропоцентрических аномальных фрагментов, связанных с атрибутами одежды героя Артура необходимо обратиться к интертекстуальным источникам, и, прежде всего, к рассказам Артура Конан Дойля. Так, в рассказе «A study in Scarlet» («Этюд в багровых тонах») при описании известного героя Шерлока Холмса встречаются те же элементы гардероба, которые, как известно, носил пальто и шляпу, ходил с поднятым воротником, в шарфе, в одном из рассказов читал газету в поезде. 
Другой пример связан с Джорджем:

\begin{tabular}{|c|c|}
\hline $\begin{array}{c}\text { Оригинал романа } \\
\text { «Артур и Джордж» }\end{array}$ & Перевод Е. Петровой \\
\hline $\begin{array}{c}\text { "Не imagines himself } \\
\text { with a hat" [Barnes 2005: 38] }\end{array}$ & $\begin{array}{c}\text { «Он уже видит, что } \\
\text { носит шляпу» [Барнс 2019: 45] }\end{array}$ \\
\hline
\end{tabular}

Шляпы для Джорджа - персонажа Дж. Барнса представляют особую важность. Этот атрибут гардероба редуплицируется автором в тексте несколько раз. Разгадать этот аномальный фрагмент вновь помогает обращение к явлению интертекстуальности, в частности, к описанию и представлению Джорджа в коротком анимационном фильме «The spacegoat» (2014). В фильме этот реально существовавший персонаж запечатлен в шляпе, которая являлась для него важным атрибутом приобщения к высшему обществу.

Следующий пример аномальных фрагментов содержит имена героев:

\begin{tabular}{|c|c|}
\hline $\begin{array}{c}\text { Оригинал } \\
\text { «Артур и Джордж» }\end{array}$ & Перевод Е. Петровой \\
\hline $\begin{array}{l} \\
\text { "... Lestrade and Gregson } \\
\text { and Hopkins and..." [Barnes } \\
\text { 2005: 343] }\end{array}$ & $\begin{array}{r}\text { «...Лестрейд, и Грегсон, } \\
\text { и Хопкинс» [Барнс 2019: 401] }\end{array}$ \\
\hline
\end{tabular}

Для определения смыслового наполнения этих имен необходимо обратиться к произведениям Артура Конан Дойля о Шерлоке Холмсе. Все персонажи с этими именами у А. Конан Дойля являются представителями закона. Лестрейд является детективом Скотленд-Ярда, Грегсон - инспектором СкотландЯрда и Хопкинс - молодым детективом. Все эти персонажи встречаются в таких рассказах, как «Этюд в багровых тонах», «Знатный холостяк», «Случай с переводчиком» и других. Отметим, что переводчик Е. Петрова не снабдила текст перевода комментариями, в результате чего «смысл остался непонятен читателю» [Морозкина, Исхакова 2019: 505].

Таким образом, анализ антропоцентрических аномальных фрагментов художественного текста представляется крайне важным для понимания имплицитных смыслов, заложенных автором в постмодернистский текст. В процессе анализа 
аномальных фрагментов в тексте «Артур и Джордж» было выявлено, что они связаны с главными героями и для разгадки, заключенных в них смыслов, переводчику необходимо обратиться к внешним интертекстуальным источникам.

\section{ЛИТЕРАТУРА}

1. Барнс Дж. Артур и Джордж: роман / Джулиан Барнс; пер. с англ. Е. Петровой. - СПб.: Азбука, Азбука-Аттикус, 2019. $544 \mathrm{c}$.

2. Бахтин М.М. Эстетика словесного творчества. М., 1986.

3. Ворожбитова А.А. Теория текста: антропологическое направление / А.А. Ворожбитова. - М.: Высш. шк., 2005. $365 \mathrm{c}$.

4. Кубрякова Е.С. Человеческий фактор в языке. Язык и порождение речи / Е.С. Кубрякова, А.М. Шахнарович, Л.В. Сахарный; отв. ред. Е.С. Кубрякова; АН СССР, Ин-т языкознания. - М.: Наука, 1991. - 238 с.

5. Кухаренко В.А., Филимонов О.Н. Об актуализации текстовых категорий. - Киев, 1991.

6. Мандрикова Г.М. Русская лексическая система в теоретическом и прикладном рассмотрении: категории агнонимии и таронимии [Текст]: автореф. дис. ... док. фил. Наук / Г. М. Мандрикова. - Москва, 2011. - 39 с.

7. Морозкина Е.А., Исхакова Э.В. Комментарий в оригинале и переводе прецедентных текстов // Вестник Башкирского университета. 2019. Т. 24. № 2. С. 503-508.

8. Морозкина Е.А., Терентьев О.С. Перевод «аномальных» прецедентов, введенных автором в семиотическое пространство англоязычного художественного текста // Вестник Башкирского университета. 2020. Т. 25. № 4. С. $927-$ 932.

9. Barnes J. Arthur and George. London: Jonathan Cape, 2005. $461 \mathrm{p}$.

(С Исхакова Э.В., 2021 г. 